\title{
INTERNET, COMPUTER AND COMMUNICATION TECHNOLOGIES IN MODERN E - LEARNING METHODS
}

\section{Jakub PACIOREK}

\begin{abstract}
This paper is focused on the teaching methods using the IT solutions for on-line learning in real time. The techniques presented are related to computer-aided teaching, with the use of the Internet. The author describes the technological infrastructure of the system, as well as its configuration and requirements as regards the bandwidth.
\end{abstract}

Key words: e - learning, distance learning, online.

\section{TECHNOLOGIE INFORMACYJNO - KOMUNIKACYJNE WE WSPÓLCZESNYCH METODACH NAUCZANIA E - LEARNING}

Streszczenie: Artykuł poświęcony jest metodom nauczania za pośrednictwem elektronicznych środków komunikacji działających $\mathrm{w}$ czasie rzeczywistym, w trybie online. Stosowane techniki dotyczą nauczania wspomaganego komputerem z wykorzystaniem Internetu. W opracowaniu opisano infrastrukturę techniczną systemu i jego konfigurację, a także wymagania dotyczące przepustowości łącza.

Słowa kluczowe: e - learning, distance learning, online.

\section{Wprowadzenie}

System kształcenia w trybie e-learningowym jest formą nauczania w której stosuje się różnorodne techniki elektronicznego przekazywania informacji. Szczegółową rolę odgrywają techniki komputerowe, w tym technologie webowe. Rozwój programów i narzędzi edukacyjnych $\mathrm{z}$ wykorzystaniem nowoczesnych technologii informacyjnych i telekomunikacyjnych pozwala na prowadzanie transmisji „na żywo”, umożliwiając interaktywność i doświadczenie jak w sali wykładowej. Metody nauczania wykorzystujące nowe $\mathrm{i}$ innowacyjne technologie $\mathrm{w}$ połączeniu z tymi bardziej tradycyjnymi zapoczątkowały powstanie tak zwanego „nauczania komplementarnego". Technologie stały się bardziej zaawansowane i ogólnie dostępne co sprawiło, że nowoczesne podejście do nauczania przekształciło się W „komplementarny e-learning", który odnosi się bardziej do wirtualnego środowiska, w jakim odbywają się lekcje. Wykorzystanie w nauczaniu różnorodnych mediów cyfrowych (dźwiękowych, wizualnych, graficznych i tekstowych) i interaktywności pozwala wykładowcy na stworzenie ciekawego i nietypowego środowiska do wirtualnego nauczania.

\section{Nauczanie w trybie synchronicznym}

Techniki przekazywania wiedzy i umiejętności za pośrednictwem Internetu mogą być realizowane na wiele różnych sposobów. Podziału dokonać można ze względu na dostępność w czasie, stosowane metody oraz techniki, relację uczeń - nauczyciel bądź też relację do nauczania tradycyjnego czy stopień formalizacji. Jedną $\mathrm{z}$ metod $\mathrm{E}$ - learningu jest jego realizacja w trybie synchronicznym.

Tryb synchroniczny jest rodzajem nauczania online, gdzie wszyscy uczestnicy tego procesu są do niego włączeni i komunikują się ze sobą na bieżąco. Nauka w trybie synchronicznym odbywa się za pośrednictwem elektronicznych środków komunikacji, takich jak czat, komunikator, audio- i wideokonferencję, telefony, dwukierunkowe transmisje rozgłoszeniowe lub wirtualna tablica. Przykładem może być wirtualna klasa, w której nauczyciel kontroluje przebieg nauczania i może odpytywać uczniów. Spełniony musi być jednak warunek jednoczesnej obecności uczących się i nauczyciela (1).

\section{Nauczanie wspomagane komputerem z wykorzystaniem Internetu \\ Komputer jest medium wielofunkcyjnym i uniwersalnym, wykazującym takie możliwości jakich nie miały dotychczas proste i złożone}


media dydaktyczne. Komputer w procesie dydaktycznym spełnia funkcję informacyjna, ćwiczeniową oraz kontrolną. Dodatkowo organizuje multimedialny przekaz treści kształcenia, stymuluje procesy i trudne sytuacje. Praca $\mathrm{z}$ komputerem rozwija umiejętności analizowania, abstrahowania czy tez klasyfikowania. Kompletny system mikroprocesorowy, poza podstawowymi funkcjami które pełni, stanowi środowisko działania platformy e - learningowej oraz wszelkiego rodzaju aplikacji i multimediów stosowanych $\mathrm{w}$ tego typu systemach kształcenia (2).

Pojęcie e - learning odnosi się do technik przekazywania wiedzy i umiejętności za pośrednictwem Internetu, należą do nich: IBT (Internet-Based Training), szkolenie online (online training) oraz nauczanie na żądanie (learning on demand). Techniki te wykorzystuja kombinację interaktywnego tekstu, grafiki i wideo. Świat wirtualny stworzony przy pomocy technologii informacyjnych IT wkracza coraz skuteczniej w realne życie, szczególnie ludzi młodych. Internet daje możliwość szybkich kontaktów między wykładowcami a uczniami oraz łatwość w przesyłaniu i modyfikowaniu materiałów dydaktycznych. Jednym ze standardów stosowanych w obszarze e learningu jest język HTML, który w ostatnich latach rozwijał się od HTML, HTML+, HTML2, HTML3, HTML4 aż do obecnie XHTML.

W ostatnich latach nastapił intensywny rozwój społeczności internetowych, któremu towarzyszy rozwój oprogramowania udostępnianego za darmo w ramach serwisów społecznościowych. Należą do nich między innymi portale: MySpace.com, grono.net, facebook.com i flickr.com. Coraz częściej służą one nie tylko do współtworzenia zawartości ale także do wymiany informacji między uczącymi się lub zdobycia istotnych danych, takich jak dane personalne czy teleadresowe, niemożliwe często do zdobycia $\mathrm{z}$ innych przyczyn. Dodatkowo istnieją aplikacje sieciowe określane mianem usług, są to blogi, podcasty i Wiki. Dzięki temu że służą do przechowywania różnego rodzaju treści, dzielenia się i zarządzania nimi, stanowią ogromny potencjał edukacyjny. Ogromne zainteresowanie oprogramowaniem społecznościowym sprawia, że twórcy systemów e - learningowych rozbudowuja platformy w tym kierunku poprzez dodawanie kolejnych narzędzi (3).

\section{Systemy zarządzające e - learningiem}

Aby umożliwić studentom i wykładowcom z różnych uczelni współpracę na poziomie platformy e - learningowej konieczna jest kompatybilność między wykorzystywanymi przez te uczelnie systemami.

Pierwszy to system zarządzania nauczaniem LMS (Learning Management System). System LMS zapewnia efektywny sposób zdobywania wiedzy i umiejętności, zapewniając użytkownikom dostęp do kursów w trybie online. System ten musi zapewnić infrastrukturę która pozwoli na zaplanowanie, dostarczenie i zarząadzanie programami e -learningu. Administratorzy systemu muszą mieć pełny dostęp do bazy danych, pozwalający im tworzyć standardy i raporty. Do stosowanych w Polsce systemów LMS należą między innymi: IBM Polska, Hewlett-Packard i Oracle.

System LCMS (Learning Content Management System) służy do zarządzania treścią nauczania. Aplikacja pomaga tworzyć, powtórnie używać, lokalizować, dostarczać, zarządzać i udoskonalać treści nauczania. Systemy LCMS są bardzo złożonymi systemami informatycznymi posiadającymi własne formaty danych, wymagane jest więc aby każdy z nich stosował się do jasno określonych standardów, zarówno w odniesieniu do współdzielonych danych, jak i sposobu komunikacji (3).

\section{Infrastruktura techniczna systemu i jego konfiguracja}

E - learning nakłada ostre wymagania co do infrastruktury technicznej systemu, w którym jest stosowany. W przypadku konfiguracji stacji roboczej wymagana jest obsługa Javy i JavaScript, rozszerzenia przeglądarki oraz zwiększenia rozdzielczości i głębi kolorów monitora. W przypadku języków programowania Java i JavaScript wymagane jest zainstalowanie odrębnej aplikacji do translacji kodu, dzięki której PC może wykonywać instrukcje. W przypadku Javy aplikacją taką jest JVM (Java Virtual Machine). Zarówno Java jak i JavaScript wchodzą zazwyczaj w skład przeglądarki. Problemy może spowodować zainstalowanie innych wersji JVM w kursie i przeglądarce. System wymaga także odpowiednich rozszerzeń dodawanych do przeglądarek webowych, są nimi: Macromedia Flash Player i Microsoft Media Player. Metody nauczania wykorzystują dźwięk, wideo i pełne animacje dlatego przeglądarka powinna zostać wyposażona W 
odpowiednie narzędzia do ich prezentacji. Powszechnie stosowane rozdzielczości monitora to: $640 \times 480,800 \times 600$ i 1024x768. Jeśli kurs opracowany jest $\mathrm{z}$ rozdzielczością większą niż rozdzielczość monitora, to uczestnik nie zobaczy na ekranie całego obrazu i będzie musiał go przewijać. Ważne jest także ustawienie liczby kolorów, najlepsze efekty uzyskuje się gdy parametry te są takie same $\mathrm{w}$ kursie $\mathrm{i}$ na monitorze (4).

\section{Wymagania dotyczące przepustowości łącza}

Pasmo to ilość danych jakie można przesłać pomiędzy punktem A i B w określonym czasie. Dostępne użytkownikom pasmo ciągle się zmienia bowiem zależy nie tylko od pasma, z jakiego korzysta łącze ale też od liczby użytkowników korzystających z łącza w danej chwili. Minimalne zapotrzebowanie na pasmo, przy założeniu że czas oczekiwania na skompletowanie jednej strony wynosi 1,9 do 2,1 s wymaga szybkości przesyłania danych z prędkością $56 \mathrm{~kb} / \mathrm{s}$. Prędkość ta daje możliwość przekazania strony nie przekraczającej $112 \mathrm{~kb}$, zawierającej obrazy, dźwięk tekst i ewentualne aplikacje. Kursy z pełnym przekazem wideo $\mathrm{i}$ audio wymagaja znacznie szerszego pasma niż wykorzystujące tylko tekst i nieruchome obrazy. Dodatkowo wszystko co doda się do treści zwiększa zapotrzebowanie na pasmo (5).

Problemy z przepustowością łączy występują zazwyczaj w trzech punktach: na łączu pomiędzy centralą a siecią WAN, w sieci WAN oraz na łączu pomiędzy siecią WAN a komputerami słuchaczy, indywidualnych lub pracujących $\mathrm{w}$ sieci LAN. Pierwszy i trzeci problem rozwiązuje się poprzez zwiększenie przepustowości linii dostępowych. Wybór technologii linii dostępowej leży w gestii zarządzającego systemem e learningu. Rozwiązanie drugiego problemu łączy się ze zwiększeniem przepustowości sieci WAN. Jest to często niemożliwe albo kosztowne. Rozwiazaniem jest zastosowanie buforowania przesyłanych treści e - learningowych. Wszystkie treści nie używane bezpośrednio można przekazać do lokalizacji ucznia przed rozpoczęciem sesji. Rozwiązanie to daje możliwość przesyłania treści w czasie gdy sieć nie jest intensywnie wykorzystywana, na przykład w nocy i weekendy.

W skład fizycznej topologii sieci CDN (Content Delivery Network) wchodzą następujące komponenty: urządzenie zarządzające i optymalizujące rozpowszechnianie treści, routery, przełączniki CF (Content Switch) oraz lokalne urządzenia buforujące i udostępniające dane. W trybie tym można rozpowszechniać dane statyczne, formaty tekstowe, HTML, PDF, JPG, GIF, Flash, MPEG, a także pliki przesyłane za pośrednictwem protokołu HTTP oraz strumienie audio i wideo. Rozwiązanie takie zapewnia kontrolowaną i inteligentną dystrybucję treści udostępnianych przez system e - learningu, a także obsługuje żądania użytkowników dostępu do treści, przekazując im za pomoca protokołu HTTP pliki (6).

\section{Podsumowanie i wnioski}

Najważniejszą korzyścią wynikająca $\mathrm{z}$ korzystania $\mathrm{z}$ systemu kształcenia $\mathrm{w}$ trybie e learningowym jest możliwość zdobywania wiedzy w dowolnym miejscu i czasie. W przypadku nauki $\mathrm{w}$ trybie synchronicznym spełnione muszą zostać odpowiednie warunki, między innymi jednoczesna obecność uczących się i nauczyciela. Taki system kształcenia daje nam możliwość zdobywania wykształcenia bez konieczności częstych dojazdów do uczelni i możliwość pogodzenia pracy z edukacją.

Elastyczne rozwiązanie kształcenia na odległość „Distance Learning” ma szczególne znaczenie dla osób zamieszkujących niewielkie miejscowości, a także osób niepełnosprawnych oraz osób pragnących łączyć sferę zawodową, rodzinną i edukacyjną. System kształcenia w trybie e - learningowym jest doskonałą forma zdobywania wykształcenia dla wszystkich, którzy cenią swój czas i wygodę. Należy jednak podkreślić, że zdobywanie wiedzy w ten sposób wymaga od uczącego się dużej samodyscypliny oraz silnej motywacji.

\section{Bibliografia}

[1] DĄBROWSKI M., ZAJĄC M. E - learning w kształceniu akademickim. Fundacja Promocji i Akredytacji Kierunków Ekonomicznych, Warszawa, 2006.

[2] JUSZCZYK S. Edukacja na odległość Kodyfikacja pojęć, regut $i$ procesów. Wydawnictwo Adam Marszałek, 2003.

[3] DĄBROWSKI M., ZAJĄC M. $e$ edukacja.net. Fundacja Promocji i Akredytacji Kierunków Ekonomicznych, Warszawa, 2007.

[4] THOMSON C., CECH J., ZIELIŃSKI K., BUTKUTE V. Metodyka szkoleń zzastosowaniem Webcastu. FOZ, Warszawa, 2009. 
[5] SIEMIENIECKI B. Komputer $w$ edukacji. Podstawowe problemy technologii informacyjnej. Toruń, 2002.

[6] HYLA M. Przewodnik po e - learningu. Oficyna Ekonomiczna, Kraków, 2005.

Recenzent: Dr hab. Henryk Noga prof. UP
Jakub Paciorek, mgr inż.

Instytut Techniki, Wydział MatematycznoFizyczno-Techniczny

Uniwersytetu Pedagogicznego im. K.E.N, ul. Podchorążych 2, 30-084 Kraków, PL tel. 0048608486466 e-mail: j-paciorek@wp.pl 